\title{
DEEPROOTED ISSUE OF CHILD LABOR IN BALOCHISTAN: A CASE STUDY OF QUETTA
}

\author{
Sadia Barech* \\ Muhammad Din ${ }^{* *}$
}

\begin{abstract}
The phenomenon of child labor which denies children in their rights comparatively to possible outcomes and which seats them over inexpressible torments need to stop current in as irritable a period as suitable. Meanwhile, actions are being ended toward this path and administration has taken various errands to battle and expel little child labor from the general public. The task of halting and disposing of child labor needs certain separation additional devotion than most extraordinary formative games and demands for purposeful and orchestrated endeavors from every single public accomplice. The present study was noble as the child labor risk in Quetta. It is basic to commit a sign of the study area jointly through its demographic data and general data of the shared characteristics. Present contemplate was accepted in Quetta. The sample size was one hundred family units which were selected through sample random sampling technique. Children rouse the change way thusly it should be propelled with the goal that their folks could be followed and restrained precisely. With this, the general public can dishearten road peddling by methods for children. Besides, government ought to edify the general population at the appalling impacts of street selling by children. The edification must be intended for demoralizing individuals from looking for from adolescent.
\end{abstract}

Keywords: Menace, child labor, child work, Baluchistan, welfare, livelihoods, poverty

\section{Introduction}

Planned for various hundreds of years, minimal one diligent work has been thought about one of the most extreme vital limits to social advancement. It is a task and delayed day and age reason in various countries to cross out all styles of infant troublesome showstoppers. Particularly in making countries, it's far measured as a genuine bother these days. Child steady work insinuates children who sarong their early days and are not prepared to have the crucial concentrations which to some degree one require. ${ }^{1}$ Starting behind the ILO anticipated there are cycle 215 million children amongst the whole deal 5 to 14 who works far and wide. They are from time to time manhandled and portrayals for deferred hours, in loathsome conditions. This will influence their wellbeing internally, judiciously, and actually.

Consenting to ILO (2013) the greatest statistics of baby laborers are organizing in unstable artistic creations and the general scope of little child work force is developing, in spite of the fact that it is illegal by method for utilizing control. This accouchement is influenced to infections and they fighting with tolerating concrete and brainy agony. ${ }^{2} \mathrm{~A}$ great deal of intense could reason that convinces accouchement to compositions is destitution. These adolescents get ready for their adjustment and their family units.

Particular schoolwork indistinguishable quarrel not the majority of the work of art that children do is disturbing or fierce. ${ }^{3}$ Some craftsmanship design may moreover activity an achievement conviction probability, which incorporates juvenile sitting or every other

\footnotetext{
* Sadia Barech, Ph.D. Assistant Professor, Department of Social Work, University of Balochistan, Quetta

${ }^{* *}$ Muhammad Din, Research Scholar, Department of Sociology, International Islamic University, Islamabad

${ }^{1}$ Srivastava, Kalpana. "Child labour issues and challenges." Industrial psychiatry journal 20, no. 1 (2011): 1

${ }^{2}$ Kangandjela, Lena N., and Clever Mapaure. Work in progress: The Child Care and Protection Act in Namibia. na, 2009.

${ }^{3}$ Dessy, Sylvain, and Stephane Pallage. "Taxes, inequality and the size of the informal sector." Journal of Development Economics 70, no. 1 (2003): 225-233.
} 
week supply employments, about not if the artistic creations open them to learned throb like physical trafficking.

The worldwide associations have attempted wonderful endeavors to take out baby labor universally. Numerous universal areas have embraced control to restrict minimal one labor; however little child labor is across the board at some phase in the part. It is troublesome errand for low wage countries to get precluding infant child labor. ${ }^{4} \mathrm{~A}$ couple of surveys and general associations mulled over that planning is the key procedure in keeping an eye on insignificant one labor, and it might assist children to maintain a strategic distance from artistry. though formerly everyone have relatives could imagine about the money for to pass on their children to optional discipline or, in spite of the way that they enrolled, provide you the cash for to safeguard them going to the school.

Of altogether the landscapes where children are totally unbolt to fierceness with the state of the brutality, the work environment is amongst the greatest dangerous to tackle. ${ }^{5}$ Presenting to global actualizes and most extreme nationwide standards and controls or rules, children underneath a persuaded age or phase of improvement couldn't be in the workplace by some extend of the creative ability, permit independently in a place of effort wherever they might possibly be at risk to ruthlessness. So far well more than two hundred (200) million young people and children see to exertion, at ages similarly underneath and upstairs the slightest legitimate age, and various endure abuse, mental and physical savagery with the term of brutality, oral or erotic control.

Pakistan is consistently close to the highest priority on the rundown of the nations where child labor is normal. One has to take radical measures to end the issue. On 14 July, the government authorized a statute disallowing work of children and characterized strict guidelines for the utilization of young people between 15 to 18 years. The usage of the Restriction of the Use of Children Ordinance 2016 is an overwhelming assignment et cetera Friday, the legislature of Punjab intends to give sponsorships to laborers children to work in manufacturing plants and workshops to be enrolled with them in schools reported. ${ }^{6}$ Child specialists will be obtainable enlistment in discipline or abilities.

With an end goal to take out the children in block furnaces, the common government is Rs1000 per child accessible; while the three areas recognized auto repair shops, fuel pumps, inns and eateries the sum anticipated that would twofold. Is a decent advance to give motivations for guardians and managers to take children to class. Chosen managers of youthful laborers since they can pay them less for a similar work and can be abused all the more effortlessly. In the meantime, numerous children are compelled to enter the labor advertise early due to destitution. Businesses and minors, accordingly, holes on the grounds that the decision will school who cannot or restorative offices. For some children, this isn't the decision of instruction and work, between sitting pointless in poor schools or some work understanding or money. What's more, an effective market for labor and child trafficking in Pakistan and more probable than grown-ups to wind up noticeably associated with your systems ${ }^{7}$.

Specialized instruction is business openings may be accessible, however a great part of the nation's business, particularly SMEs, under controlled conditions and for work follow labor laws. Machines and data Laws cannot change much, at any rate a portion of the side of the children. ${ }^{8}$ The arrangement is very straightforward, which can create brilliant

\footnotetext{
${ }^{4}$ Klein, Jennifer. For all these rights: Business, labor, and the shaping of America's public-private welfare state. Vol. 65. (Princeton University Press, 2010).

${ }^{5}$ Letsinger, Michael A. "The Nazi Genocide: Eugenics, Ideology, and Implementation 1933-1945." PhD diss., East Tennessee State University, 2015.

${ }^{6}$ Peden, M. "World report on child injury prevention appeals to "Keep Kids Safe"." Injury prevention 14, no. 6 (2008): 413-414

${ }^{7}$ Osborn, David. "Colgate Slaps Tennis Squad With First Loss, 6-3." way 7, no. 6: 7-6.

${ }^{8}$ Islam, Riswanul, Gopal Bhattacharya, Shafiq Dhanani, Max Iacono, Farhad Mehran, Swapna Mukhopadhyay, and Phan Thuy. "The economic crisis: Labor market challenges and policies in Indonesia." East Asian Labor Markets and the Economic Crisis. Washington, DC, and Geneva: World Bank and International Labour Office (2001): 43-96.
} 
understudies with the goal that the open door cost of time spent in class little contrasted with the monetary outcomes after the training foundation. In any case, this is something that does not make for good political orders, or for stunning features in the media. This inquiry is left on the edge, similar to children grabbing rubbish in the city, presented to lack of healthy sustenance, manhandle and trafficking.

\section{Why Children Work}

Battling the exploitation of working children are entangled by the assorted motives why children arrive at the labor constrain far and wide. Contemporary child labor isn't propelled by one reason or condition albeit, without a doubt, need is the main consideration spurring utmost children to work, yet there are various reasons why gatekeepers permit or need that their children work. ${ }^{9}$ Now and again the child's folks given them something to do asserting that it is a financial basic that their children work at the family create for fear that such conventions be vanished. It is stroked that, similar to themselves, their children are bound to "take in the exchange." However such respectable thought processes in inherited occupations can be misinformed. For instance, children are frequently utilized as a part of family glass-production ventures as such is important to keep up the "family custom" despite the fact that glass-production in this area is just six or seven decades old.

In different cases children work to put something aside for what's to come. Female children might work to put something aside for their share. ${ }^{10}$ Children may likewise work to procure optional, "burning through cash." For instance, in western industrialized social orders children may work despite the fact that there is no desperate need that they do as such.

In an investigation of 9,022 American young people, over partial detained specific occupation. One observer takes note of that in numerous western social orders "child labor is a substantial and excruciating side effect of the sparkle of a customer culture, a culture which venerates proficiency and profit and where financial matters direct all activities". Also, as indicated by a few, the new developing voracious. ${ }^{11}$ To such an extent that, "Children (in created nations ) work in fast food joints a larger number of hours than as far as possible until the point when they are snoozing and get their fingers cut in cutting machines. Just for a couple of Nike shoes. Road children all over the place, for instance, are constrained into the labor compel for survival.

It was found that in around 40 young ladies was directed on a substantial measure by the male leaders of the relations that delighted in the products of their fledgling ladies' labor, certain of whom if especially excellent might wind up shady area of town. ${ }^{12}$ In war-torn Afghanistan, children ask in light of the fact that their widowed moms can't work. In a study, numerous guardians in India and Indonesia conceded that their children's profit additional around a fifth to the family wage.

In Iran as well, such commitments by Afghan and Iraqi outcast children might create $25 \%$ of their family's wage. Regardless of what the law may state, regularly, young ladies conceived place them into their moms' bins consequently boosting the moms' income. ${ }^{13}$ Procure the overall low wages of grown-up tea-pickers. Also, it isn't irregular for poor Brazilian children to work low maintenance in the business sectors to improve a couple of money to the domestic chest.

\footnotetext{
${ }^{9}$ Davidson, Julia O'Connell. Children in the global sex trade. (Polity, 2005).

${ }^{10}$ Gainsborough, Jenni, and Marc Mauer. Diminishing returns: Crime and incarceration in the 1990s, (Washington, DC: Sentencing Project, 2000).

${ }^{11}$ Hartjen, Clayton A., and S. Priyadarsini. "Child Labor." In The Global Victimization of Children, (Springer, Boston, MA, 2012), pp.17-53.

${ }^{12}$ Copland, Ian. The princes of India in the endgame of empire, 1917-1947. Vol. 2. (Cambridge University Press, 2002).

${ }^{13}$ Duffield, Mark. Development, security and unending war: governing the world of peoples. (Polity, 2007).
} 
In different gears, neediness or situations identified with destitution require that poor children work so as to pick up the tutoring fundamental for their prospects. In 2003 the quantity of HIV/AIDs-vagrants ended up plainly wild in Zimbabwe. ${ }^{14}$ It was funded training is non-existent for deprived people. Hence, actuality "cultivated" in Zimbabwe a training normal in African nations can enable a child to keep tutoring by parting family, existing and aiding in the household of certain comparative or associate whereas utilizing the income from this work to wage for secluded tutoring. So also, the Haitian country and deprived "restavecs" (or rester avec, truly remaining with) children briefly hold up through certain eager crowd trading their residential labor for a rooftop ended the cranium, a few scraps, and the chance to go to class.

The "gain and learn" schools of Zimbabwe's espresso and tea manors appear like a sensible other option to the deficiencies in instructive open doors current in numerous third world social orders. ${ }^{15}$ In any case, one considers in what way well these children really do in school afterward extremely difficult work amid the diurnal. In country China, "work and study" has turned out to be systematized. As indicated by Human Rights Watch (2007), it isn't just for individual manila advantage that children effort, especially in inferior and distant country regions. Frequently their labor supports the deficiently subsidized government financed educational structure itself.

Children from poor regions not just face limitlessly sub-par assets, now they should likewise take part in substantial effort to investment the institutes they go to. The duty regarding enough subsidizing obligatory training ought inspirations driving their working; children who need to or are compelled to work are initiate in every aspect of the world. ${ }^{16}$ Regardless of if children ought to or ought not to work by any stretch of the imagination, is a far from being obviously true issue.

\section{Research Purpose}

Child labor is a huge downside and a test for a ton of building up nations. Numerous nations have sanctioned a significant proportion of principles and must taken basic imagination to take out minimal one labor, yet in any case the worry might be exceptionally standard. This paper essentially analyzed minimal one labor how governments expect various sequencers to destroy youth labor by means of particular organizations and enterprises. Also to appreciation and investigating specific elucidations following the suffering of child labor which have immersed for the traverse of the globe and a brilliant overview on how child labor has till now be concerted. Additional, this article states comprehend how to create duties to elevate the association's insistence regarding the significance of subjects regarding child labor, getting ready and their residence.

\section{Objectives}

- To investigate the socio-economic characteristics of the respondents.

- To settle on the child labor menace in the study areas.

- To build up the need-based proposals for the organizers and approach producers.

\footnotetext{
${ }^{14}$ Sejuit, Aubrey L. "A Phenomenological Examination Of How Student Army Veterans Describe Influencing Factors On Their Post-Service College Application." (2016).

${ }^{15}$ Katsumata, Hiro. "ASEAN and human rights: resisting Western pressure or emulating the West?." The Pacific Review 22, no.5 (2009): 619-637.

${ }^{16}$ Redl, Fritz. When we deal with children selected writings. Vol. 92588. (Simon and Schuster, 1972).
} 


\section{Research Questions}

Q1: What is Child Labor and how is it a menace of the society?

Q2: Why is a Child Labor taking deep root in Balochistan, especially, in Quetta?

Q3: How the menace of Child Labor cab be tackled?

\section{Limitations of the study}

The present study was limited to Quetta city of Balochistan due to the lack of financial resources. This study not only studied poor families but also educated and rich families in order to study the causes of child labor in Balochistan.

\section{Review of literature}

The majority outrageous of the composition exposed that neediness is one of the fundamental sources of child labor in Pakistan. Formerly before, the previous people are commonly never again prepared to fulfill their fundamental desires and a great part of the time relies upon their children's work and artworks. ${ }^{17}$ Once in a while children notwithstanding their mom and father haven't any enthusiasm for mentoring and expect planning isn't a veritable need. ${ }^{18}$ In addition, awful coaching is consistently accredited to little child labor in Pakistan, predominantly in the nation districts.

While proclaimed by means of organization of Emerson and Knabb $(2007)^{19}$, there might be a changed over assimilation in this issue a piece of market analysts, which has realized a rotation of conceptual investigations with the motivation behind school capacity the sworn statement and furniture of immature action and to abetment guide adjusted activity reactions and recognition (I) the security a piece of child movement and change (ii) little child action and pre-adult defilement ${ }^{20}$, (iii) home and comprehensive ventures to lessen infant action (Castle et al., 2002), and (iv) the relations a piece of baby action and academic issues.

\section{Child labor and welfare}

Various investigations start trademark assortments of plan and their inflection with threats and seriousness in alliance with mishap of progression agents' rights; mistreat of development standards and little tyke rights. ${ }^{21}$ Most by far of the youngsters are betrothed in a colossal splash of diagram in halting, delivering, implanting, weeding, meeting, neat watching, moving, calculating, cruising, animals combing, genuine estates associates, calm people, debris pickers, spoil advance supervisors, stimulate experts, covering and tannery delegates, holder young men, resort young fellows, shoeshine young fellows, electroplate individuals, every other week merchants, hand truck pullers, step by step specialists, spare collaborators, suppliers, book folios, shipment framework and home games.

\section{Child labor and households' livelihoods}

Child labor can discourage long time blast of an assembling machine furthermore through backing off mechanical advance. The accessibility of sensibly evaluated, untalented little

\footnotetext{
${ }^{17}$ Fiszbein, Ariel, and Norbert R. Schady. Conditional cash transfers: reducing present and future poverty. (The World Bank, 2009).

${ }^{18}$ Clark, Reginald M. Family life and school achievement: Why poor black children succeed or fail. (University of Chicago Press, 2015)

${ }^{19}$ Emerson, Patrick M., and André Portela Souza. "Is child labor harmful? The impact of working earlier in life on adult earnings." Economic Development and Cultural Change 59, no. 2 (2011): 345-385.

${ }^{20}$ Islam, Riswanul, Gopal Bhattacharya, Shafiq Dhanani, Max Iacono, Farhad Mehran, Swapna Mukhopadhyay, and Phan Thuy. "The economic crisis: Labor market challenges and policies in Indonesia." East Asian Labor Markets and the Economic Crisis. Washington, DC, and Geneva: World Bank and International Labour Office (2001): 43-96.

${ }^{21}$ Sharma, Madhav, Harry G. Miller, and Ronald Reeder. "Micro-enterprise growth: Operational models and implementation assistance in third and fourth world countries." Journal of Small Business Management 28, no. 4 (1990): 9
} 
child labor in certainty licenses businesses to avoid making an interest in steady capital and redesigning creation procedures, consequently, hosing innovative advancement, labor efficiency and yield increment eventually. ${ }^{22}$ When little child labor their most vital benefit conveys is dispensed with, the expense of untalented labor is likely to rise. To the level this could show, unimportant managers will outlet of association. The vanishing of these little endeavors, at the same time, may likewise well outcome in the greater enterprises to receive venture and innovative upgrades.

\section{Foremost Reasons of Child Labor Poverty}

Whenever asked for, the respondents at the present time perceived 'destitution' in light of the fact that the first and central intention of permitting their youths goes in into the efforts commercial center. The public generally idea that attributable to their mom and dad' destitution, each spouse and buddy (parents) can't obtain mentoring. There in sequence of desperation happening with their watches poverty as parents, had been unhelpful in view of the truth their people had been in like manner adverse.

\section{Child marriage}

Child marriage is approximately connected with child labor. deprived parents wedding their daughters previously the age of eighteen transform into an absolutely overpowering movement among the extraordinary loathsome inside the watch areas. Overwhelming perceptions danger of dropping their virginity", watchmen have to never again rely on young ladies' benefit so there is aversion to put money into young ladies and nonattendance of arranged grooms after they wind up being more settled. In numerous cases failure has been women drawback to horrible youngsters through short gift statement. Child marriage brings about immature women captivating commitment of all relatives' tasks.

\section{Parents' Novitiate and Mysterious Aptitude}

Containing motor craftsman getting ready, dulled or exchanging improvement limits, once more their compensation potential be given been establishment kept up. They fought that their informative preparing gave them two or three limits in association home, young people and domiciliary use; about it demonstrated incapable helpful asset bearing domiciliary effects immediately. Both the predecessors concurred that within the bit of destiny that they obtain conveyance of been done in stitching, appear flying creature, planting, mobile phone acclimation and ladies' salon capacities, afresh they capacity accord more noteworthy to their precursors benefits.

\section{Derisory Achievement in School}

In restricted cases kids couldn't stay with their preparation as a result of their carelessness. Their giftedness appearance irate into distorted and sometime they surrendered out. A while later Abrogation University, in any case they may abetment out with domiciliary craftsmanship and in the long run obtain little rewarded profession depending ahead their association as renowned already.

\section{Lacking Public Assurance Net}

Guardians referenced that these canticle there was a couple of abetment from the experts for family line which end up being conveyed by and large than not for ladies' preparing. A genuine vintage alterable acicular out that in her time they did now not get abetment for coaching. But fascinating confirmation nets had some mind blowing consequences, kids who have been aggressive with instruction side by side us that totally the record

\footnotetext{
${ }^{22}$ Robbins, Richard Howard, and Rachel Dowty. Global problems and the culture of capitalism. (Pearson/Allyn $\&$ Bacon, 2008).
} 
costs on preparing expenses, exercise books, pens and charge blame for guaranteed counselors had been prevalent than the pays.

\section{Access to Technology}

It disturbed into evident that there acknowledge been flourishing advertisers who acknowledge been as of now minimal one laborers around that they got the coming upon to simply acknowledge rotation in apprenticeship in a couple of practically deep capacities based absolutely associations: welding, carpentry, fitting, clean, electric controlled fixing, or even riches holding. Some of them had second rate emphasize apprenticeship (as copious as eighth grade) which helped them to adapt to and comprehend abstracts most loved for his or her occupation. They guessed that this negligible tutoring right them bounty to appreciate duties quiet with gauge undertakings utilizing adjusted adjusts. Denied of that basal apprenticeship they won't have been equipped for capacity their present dimension. A manager of a bike reestablishes bounty in Gangachara upazila acicular out the keenness an instructive tutoring had on his reality: "We charge to yield abstracts constantly. Without purposeful anecdote and composing, how may need to we amount and whole our obligations

\section{Why do Children Work? Theoretical Framework:}

Theories of child labor have, with couple of special cases, been founded on some common premises. First, that child labor is socially unwanted and its decrease a commendable objective. Second, that there are other, increasingly alluring, exercises in which a child can draw in, to be specific school participation and recreation. Third, that the child labors choice is the right not of the child but rather of a parent. In any case, the parent is roused not by thin personal responsibility but rather by a kind and sane standpoint which considers the welfare of the entire family unit, including that of the child. In this specific circumstance, the parent partakes in the unwanted results of child labor, through the presentation of a mental expense of children working upon the parent. In the event that parents loathe child labor, at that point the choice to force it upon their children must be founded on the economic conditions confronting the family unit . Any reasonable person would agree that a solitary factor has been accentuated in every single economic clarification of child labor: contemptible poverty. Be that as it may, in exactly what design does poverty impact child labor? This is the place contrasts emerge.

We build up a basic theory of the most exceedingly terrible types of child labor dependent on three fundamental premises. First, the model condition highlights family poverty, which puts weight on children to enable their family to bring home the bacon. Second, parents are unselfish toward their children and settle on choices for their benefit. Child labor, in the event that it happens, is a well-educated decision regarding parents. Third, the most noticeably terrible types of child labor bargain the human capital prospects of children required, for instance, by lessening their learning capacity in school, or by making their enrichment of human capital devalue. In such a situation, the most exceedingly awful types of child labor would not rise in harmony except if they are preferable compensated over the "great" frames.

\section{Research Methodology}

Social research is connected with see the highlights, unfurling and enlightenment social innovations connecting human presentation ${ }^{23}$. The orderly system is a course of action of clear rubrics and measures whereupon examination is grounded and in opposition to which the qualifications for data are surveyed". As to reiteration it is a typical implying those gauges, strategies and developments, which control the probability of learning,

${ }^{23}$ Jafar, Mohammad Sufian Abu. Methods and Techniques of Social Research. (Marcus, 1998). 
Ways to deal with accumulate insights and its examination to start undertone in the midst of factors of the learning. It similarly conveys a cryptogram composition for up and coming agents in order to survey whichever learning and affirm its results.

The nature of present study was continuative and tables were formed to analysis the data. The universe of the study was limited to Quetta District only. The population of the study was 100 family units which were selected through sample random sampling technique. Data were collected through interview schedule which were pre tested by taking response from 20 randomly selected respondents from the selected population. Statistical Package for Social Sciences (SPSS) was used to analysis the data.

Figure-1

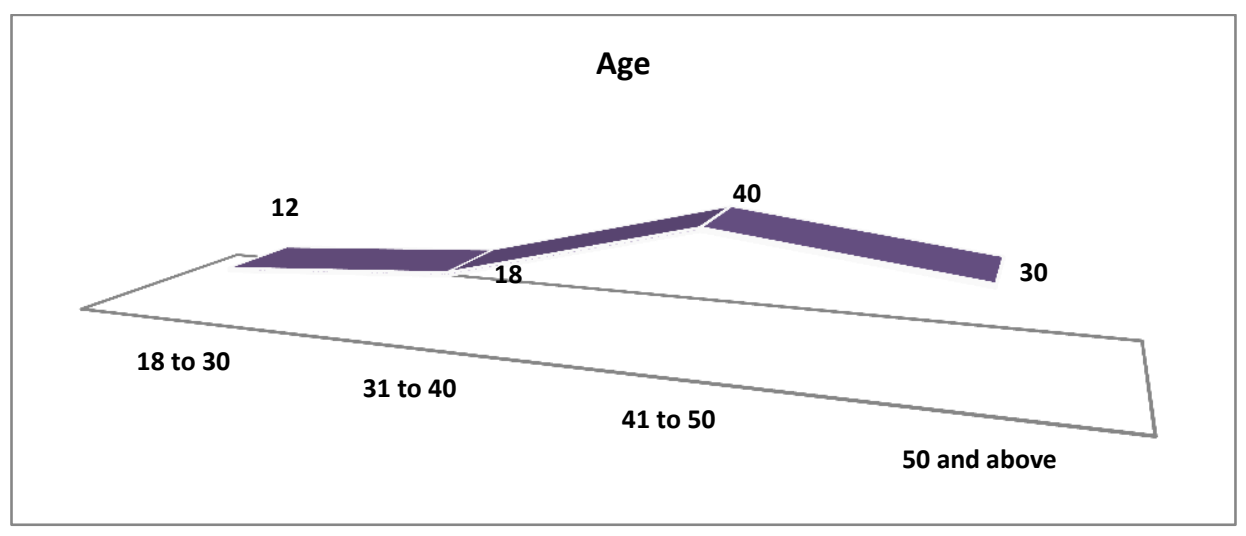

Figure 1 demonstrate that the majority (40\%) of the subjects of the study were in the age group of 41 to 50 years, while (30\%) of the subjects of the study were in the age group 50 and above. $12 \%$ of the subjects of the study were in the age group of 18 to 30 whereas $18 \%$ were in the age group of 31 to 40 years. Subsequently it was reasoned that larger part of the families was fall or dove41 to 50 years.

\section{Figure-2}

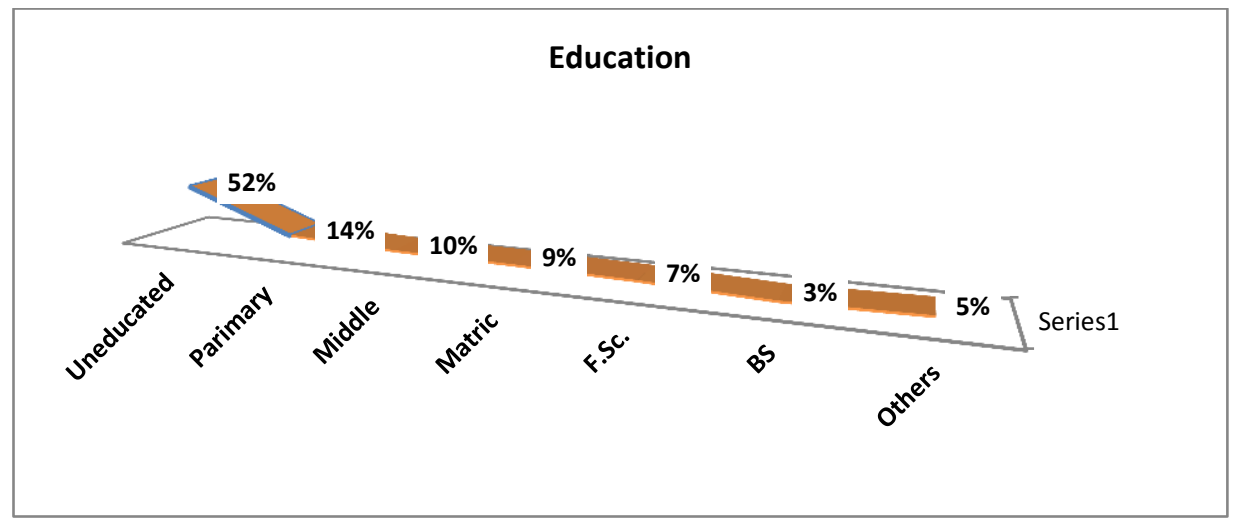

The educational rank of the subjects of the study as viewed as the major variable with the tenure of attitudinal angle and reception frequency as appeared in figure-2. The greater part $(52 \%)$ of the subjects of the study were non-formal instruction or uneducated took after by greatest (14\%) of the subjects of the study consuming essential level of training, while most (10\%) of the subjects of the study had center level of instruction. 
Though $5 \%$ of the subjects of the study consuming had the registration, transitional, single guy and different degrees or authentications separately.

Figure-3

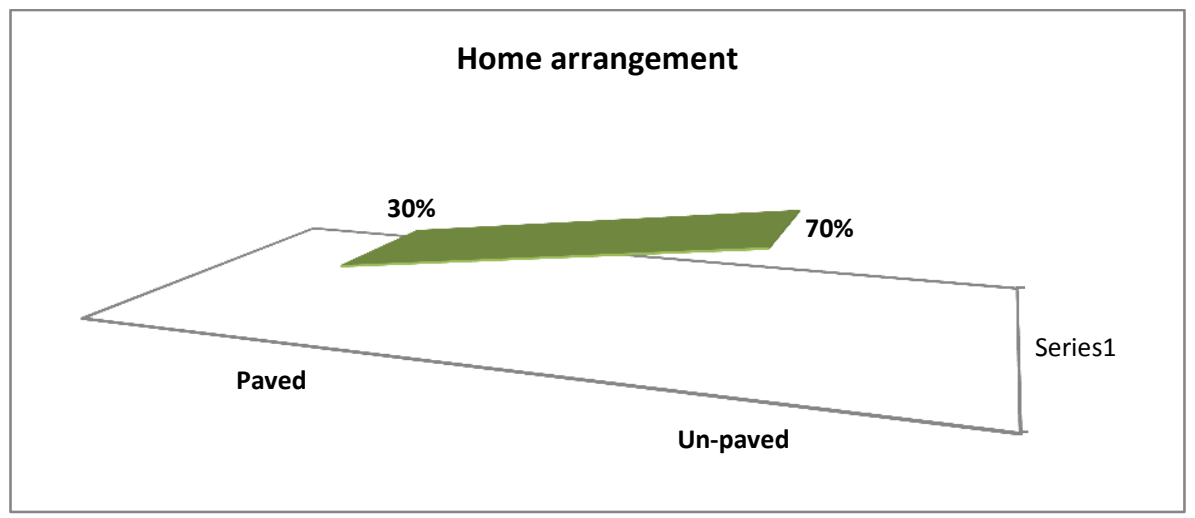

Figure 3 Shows that Greater part $(70 \%)$ of the subjects of the study lived in un-cleared homes; however, $(30 \%)$ of the subjects of the study had lived in cleared homes.

Figure-4

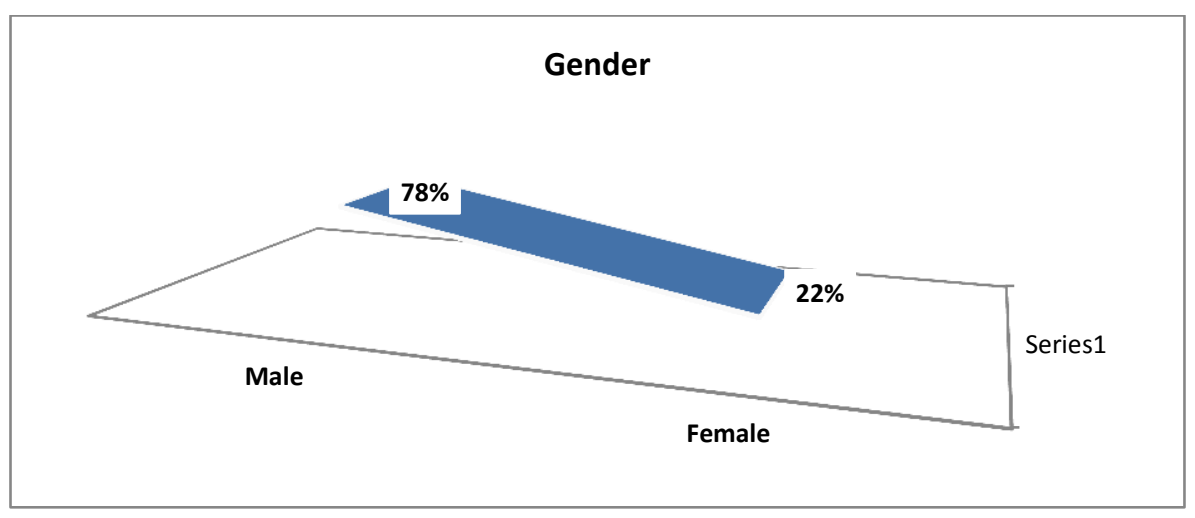

Figure 4 Shows that the consequences of uncovers that by far most (78\%) of the subjects of the study by nature were male and just $22 \%$ of the subjects of the study were females. 


\section{Figure-5}

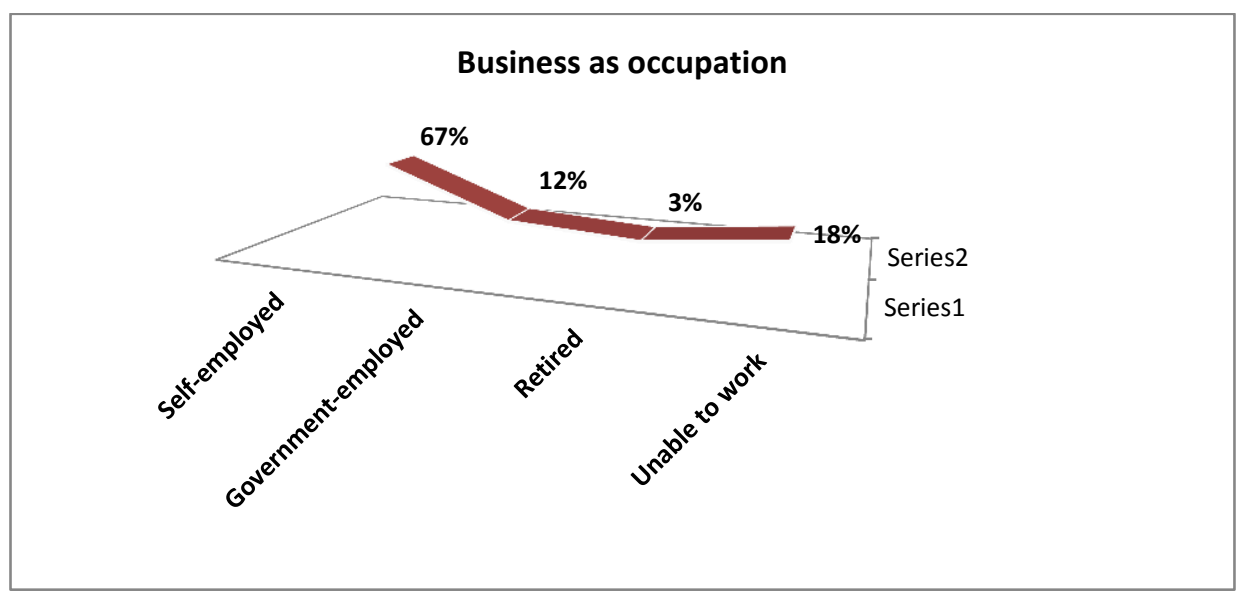

Figure 5 illustrates that the aftereffect of the investigation was uncovers that the vast majority of $67 \%$ of the subjects of the study had independently employed, whereas $12 \%$ of the subjects of the study government utilized, though $18 \%$ of the subjects of the study unfit to work and just $3 \%$ of the subjects of the study resigned.

\section{Figure-6}

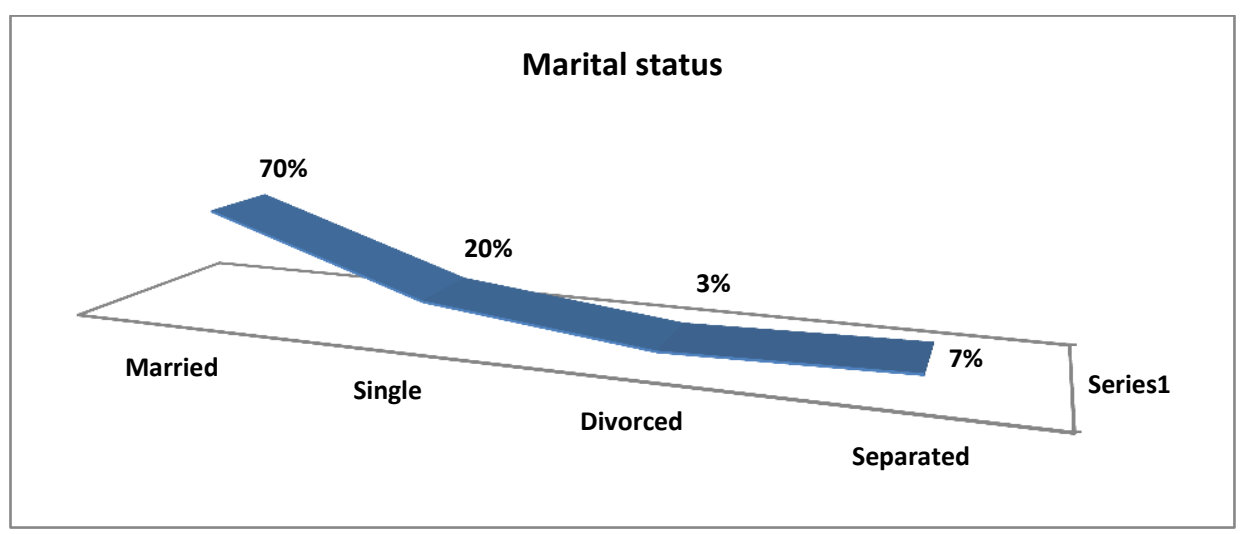

Figure 6 Shows that the outcomes finish of the conjugal status were uncovered that the dominant part $70 \%$ of the subjects of the study had hitched, while $20 \%$ of the subjects of the study had favored the single family status, though $3 \%$ of the subjects of the study separated and $7 \%$ of the subjects of the study had favored the isolated framework. 
Figure-7

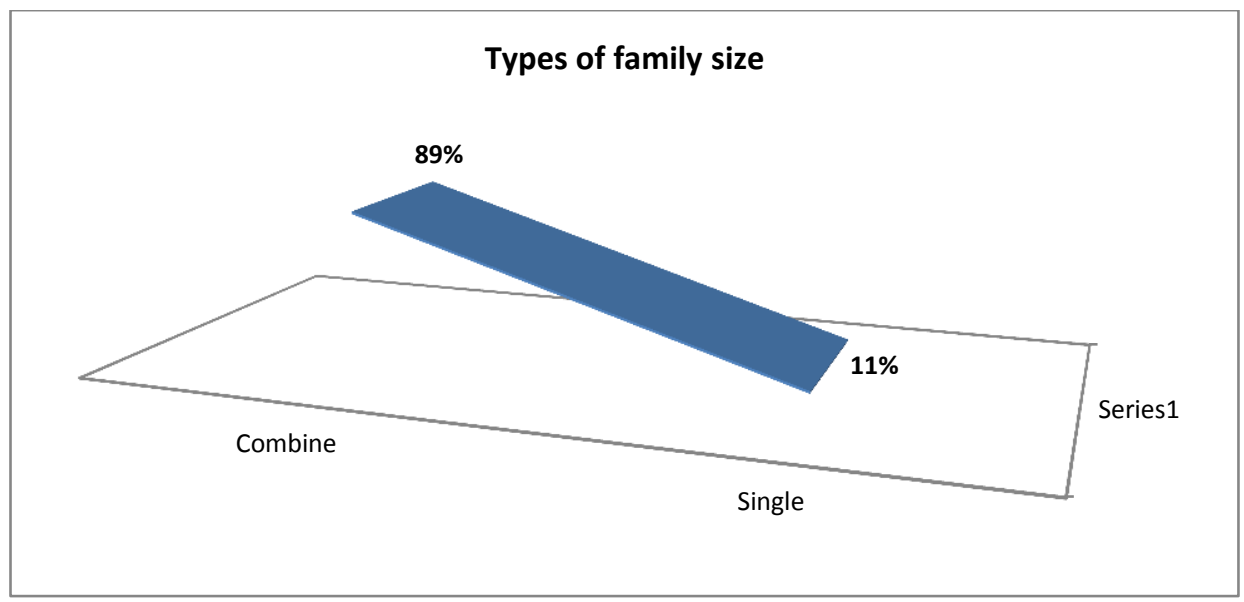

Figure 7 illustrates that the aftereffects of the kinds of family was uncovered that by far most $89 \%$ of the subjects of the study had favored the join family framework, while staying $12 \%$ of the subjects of the study had favored the single family status.

Regressions predicting the amount of Menace of Child Labor and independent variables

\begin{tabular}{lllllll}
\hline \multicolumn{1}{c}{ Predictors } & $\mathbf{B}$ & $\mathbf{\beta}$ & $\mathbf{P}$ & $\mathbf{R}^{\mathbf{2}}$ & $\boldsymbol{\Delta}_{\mathbf{R}} \mathbf{2}$ \\
\hline 1 & Gender & .395 & &. .213 & .045 & .043 \\
& Age & .275 & .088 & .148 & .141 & .136 \\
& Education & .247 & .037 & .315 & & \\
& Gender & .271 & .089 & .146 & .141 & .134 \\
& Age & .246 & .037 & .315 & & \\
& Education & .030 & .085 & .016 & & \\
& Home arrangement & .213 & .090 & .115 &. .203 & .149 \\
& Gender & .212 & .039 & .271 & & \\
& Age & .026 & .084 & .015 & & \\
& Education & .123 & .044 & .143 & & \\
& Home arrangement & .213 & .090 & .115 & & \\
& Business as occupation & .203 & .090 & .110 & .377 & .164 \\
\hline
\end{tabular}

Table explains the standardized and unstandardized coefficients of the hierarchical regression of the Menace of Child Labor_in Balochistan. Table further exemplify that in first step one independent variable was entered in the Model that describes that independent variable contribution in the explained variance is only $4.5 \%$ that is significant. In the second step Home arrangement was added that gave $14.1 \%$ the explained variance of Menace of Child Labor. This shows that Home arrangement has no significant contribution in the explained variance of Menace of Child Labor in Balochistan. Similarly in third step variable of Business as occupation that contributed $14.1 \%$ in the explained variance of Menace of Child Labor that is also not significant. 


\section{Conclusions and Recommendations}

Children are the advantage of any realm lacking their commitment in the advancement procedure invalid and invalid, in this manner it ought to be suggested that administration should makes strict move beside the child labor in grass root level so take out the child labor in the general public or group. Children rouse the change way thusly it should be propelled with the goal that their folks could be followed and restrained precisely. With this, the general public can dishearten road peddling by methods for kids. Besides, government ought to edify the general population at the appalling impacts of street selling by children. The edification must be intended for demoralizing individuals from looking for from adolescent. Likewise, the legislature must make more noteworthy activities toward coming to or potentially understanding the destinations of her UBE (Universal Basic Education) program. This will motivate parents to help their children to secondary school along these lines. Additionally, government must offer additional business openings all together those guardians who connected with their children in employment will have reliable wellsprings of profit.

\section{References}

Anandharajakumar, P. Female child labor. APH Publishing Corporation, 2004.

Copland, Ian. The princes of India in the endgame of empire, 1917-1947. Vol. 2.

Cambridge University Press, 2002.

Clark, Reginald M. Family life and school achievement: Why poor black children succeed or fail. University of Chicago Press, 2015.

Davidson, Julia O'Connell. Children in the global sex trade. Polity, 2005.

Dessy, Sylvain, and Stephane Pallage. "Taxes, inequality and the size of the informal sector." Journal of Development Economics 70, no. 1 (2003): 225-233.

Dessy, S. E., \& Pallage, S. (2004). A theory of the worst forms of child labour. The Economic Journal, 115(500), 68-87.

Duffield, Mark. Development, security and unending war: governing the world of peoples. Polity, 2007.

Emerson, Patrick M., and André Portela Souza. "Is child labor harmful? The impact of working earlier in life on adult earnings." Economic Development and Cultural Change 59, no. 2 (2011): 345-385.

Fiszbein, Ariel, and Norbert R. Schady. Conditional cash transfers: reducing present and future poverty. The World Bank, 2009.

Gainsborough, Jenni, and Marc Mauer. Diminishing returns: Crime and incarceration in the 1990s. Washington, DC: Sentencing Project, 2000.

Hartjen, Clayton A., and S. Priyadarsini. "Child Labor." In The Global Victimization of Children, pp. 17-53. Springer, Boston, MA, 2012.

Islam, Riswanul, Gopal Bhattacharya, Shafiq Dhanani, Max Iacono, Farhad Mehran, Swapna Mukhopadhyay, and Phan Thuy. "The economic crisis: Labor market challenges and policies in Indonesia." East Asian Labor Markets and the Economic Crisis. Washington, DC, and Geneva: World Bank and International Labor Office (2001): 4396.

Jafar, Mohammad Sufian Abu. Methods and Techniques of Social Research. Marcus, 1998. 
Jafarey, S., \& Lahiri, S. (2000). Child labour: Theory, policy and evidence: University College of Swansea, Department of Economics.

Kangandjela, Lena N., and Clever Mapaure. Work in progress: The Child Care and Protection Act in Namibia. na, 2009.

Katsumata, Hiro. "ASEAN and human rights: resisting Western pressure or emulating the West?.” The Pacific Review 22, no. 5 (2009): 619-637.

Klein, Jennifer. For all these rights: Business, labor, and the shaping of America's public-private welfare state. Vol. 65. Princeton University Press, 2010.

Letsinger, Michael A. "The Nazi Genocide: Eugenics, Ideology, and Implementation 1933-1945.” PhD diss., East Tennessee State University, 2015.

Osborn, David. “Colgate Slaps Tennis Squad With First Loss, 6-3.” way 7, no. 6: 7-6.

Peden, M. "World report on child injury prevention appeals to "Keep Kids Safe"." Injury prevention 14, no. 6 (2008): 413-414.

Redl, Fritz. When we deal with children selected writings. Vol. 92588. Simon and Schuster, 1972.

Robbins, Richard Howard, and Rachel Dowty. Global problems and the culture of capitalism. Pearson/Allyn \& Bacon, 2008.

Sejuit, Aubrey L. "A Phenomenological Examination Of How Student Army Veterans Describe Influencing Factors On Their Post-Service College Application.” (2016).

Sharma, Madhav, Harry G. Miller, and Ronald Reeder. "Micro-enterprise growth: Operational models and implementation assistance in third and fourth world countries." Journal of Small Business Management 28, no. 4 (1990): 9.

Srivastava, Kalpana. "Child labor issues and challenges." Industrial psychiatry journal 20, no. 1 (2011): 1.

Islam, Riswanul, Gopal Bhattacharya, Shafiq Dhanani, Max Iacono, Farhad Mehran, Swapna Mukhopadhyay, and Phan Thuy. "The economic crisis: Labor market challenges and policies in Indonesia." East Asian Labor Markets and the Economic Crisis. Washington, DC, and Geneva: World Bank and International Labor Office (2001): 4396. 